\title{
Impact of ABO- and Rh- incompatibility in allogeneic hematopoietic stem cell transplantation
}

\author{
Maxim A. Kucher ${ }^{1}$, Dmitrii E. Pevtcov ${ }^{1}$, Polina S. Kuga ${ }^{1}$, Boris I. Smirnov ${ }^{1,2}$, Alexander L. Alyanskiy ${ }^{1}$, \\ Natalia E. Ivanova ${ }^{1}$, Maria A. Estrina ${ }^{1}$, Elena V. Babenko ${ }^{1}$, Burkhonidin B. Bakhovadinov ${ }^{1}$, Ludmila S. Zubarovskaya ${ }^{1}$, \\ Boris V. Afanasyev ${ }^{1}$ \\ ${ }^{1}$ R. Gorbacheva Memorial Institute for Children Oncology, Hematology and Transplantation; Chair of Hematology, Transfusiol- \\ ogy and Transplantation at the First St. Petersburg State I. Pavlov Medical University, St.P etersburg, Russia \\ ${ }^{2}$ St. Petersburg State Electrotechnical University «LETI», St. Petersburg, Russia
}

Dr. Maxim A. Kucher, Head, Department of Clinical

Nutrition, R. Gorbacheva Memorial Institute for Children

Oncology, Hematology and Transplantation; Pavlov First

Saint Petersburg State Medical University, Russia;

L.Tolstoy St. 6-8, 197022
Phone: +7(921) 9939902

E-mail: doctorkucher@yandex.ru

Citation: Kucher MA, Pevtcov DE, Kuga PS et al. Impact of ABO- and Rh- incompatibility in allogeneic hematopoietic stem cell transplantation. Cell Ther Transplant 2018; 7(4): 38-46

\section{Summary}

Currently, there are conflicting data on the impact of recipient/donor $\mathrm{ABO}$-incompatibility upon development of complications and effectiveness of treatment in allogeneic hematopoietic stem cell transplantation (allo-HSCT). The aim of our study was to specify the role of ABO- and Rh- incompatibility in allo-HSCT for a well-characterized cohort of patients.

\section{Patients and methods}

From 1999 to 2015,1132 patients with malignancies and hereditary diseases were subjected to 1482 allo-HSCTs at the R. Gorbacheva Memorial Institute for Children Oncology, Hematology and Transplantation. Their age was from 6 months to 76 years, at a median of 25 years old. A comprehensive statistical analysis in different comparison groups was carried out, in order to determine the impact of ABO-incompatibility, either as isolated finding, or in combination with other factors, upon overall survival (OS), time and ability of engraftment, posttransplant complications, i.e., hemolytic conditions, acute and chronic graft-versus-host disease (GvHD) observed in the allo-HSCT patients. Predictive models of OS were created.

\section{Results}

ABO-incompatibility was determined in $54.6 \%$ of cases $(\mathrm{n}=780)$ : major $-37.8 \%(\mathrm{n}=295)$; minor $-45.4 \%(\mathrm{n}=354)$; bidirectional - $16.8 \%(n=131)$. In patients with leukemia, a negative impact on OS D+100 was revealed for minor ABO-incompatibility, as compared to ABO-compatible allo-HSCT (respectively, $85 \%$ and $91 \%, \mathrm{p}=0.05$. Combination of myeloablative conditioning regimen and major ABO-incompatibility $(\mathrm{n}=37)$ was associated with reduced OS during early period $(\mathrm{D}+100)$ compared to $\mathrm{ABO}$-compatible allo-HSCT $(\mathrm{n}=103$, respectively, $76 \%$ and $91 \%, \mathrm{p}=0.025)$. The presence of $\mathrm{ABO}$-incompatibility did not increase the risk of acute and chronic GvHD in patients with leukemia, $\mathrm{p}=0.85$.

\section{Conclusion}

ABO-incompatibility in combination with other mutually potentiating factors can correlate with decreased therapeutic efficiency by the $\mathrm{D}+100$, and during first year after allo-HSCT, thus requiring selection of ABO-compatible graft donors, if possible, and demands for high-quality prophylaxis and sophisticated transfusion therapy to prevent hemolytic complications.

\section{Keywords}

Hematopoietic stem cell transplantation, ABO-incompatibility, complications. 


\section{Introduction}

Allogeneic hematopoietic stem cell transplantation (alloHSCT) is effective method of treatment for malignancies, some solid tumors and hereditary diseases in children and adults [1]. The main success factors are dependent on the underlying disease status at the time of therapy initiation, and the level of HLA-match between recipient and donor of hematopoietic stem cells which is a key factor to increase the chance for engraftment, and to reduce development of acute and chronic graft-versus-host disease (GvHD) [2].

Since the beginning of allo-HSCT implementation as a treatment method from the middle of the XX century, there is a great progress in accessibility and safety of this treatment approach. However, ABO- and Rhesus-incompatibility between patient and donor in allo-HSCT are shown in 30-50\% of cases, thus leading to additional complications and erythrocyte recovery delay $[3,4]$. The presence of ABO-incompatibility requires higher level of immunological security measures while providing replacement transfusion therapy: compliance with $\mathrm{ABO}$-compatibility rules, depending on the level of posttransplant chimerism; X- or $\gamma$-irradiation of erythrocyte and platelet-containing blood products before transfusion, leukofiltration technology [5].

There are three ABO-incompatibility types - minor (20$25 \%$ of all cases), major (20-25\%) and bidirectional (5\%) (Table 1) [6].

ABO-incompatibility may predispose for some severe complications, such as acute and delayed hemolysis, pure red cell aplasia (PRCA) [7], GvHD [8], graft failure [9], autoimmune hemolytic anemia [10], which negatively affect the effectiveness of HSCT by increasing mortality [11]. At the same time, there are studies which yield conflicting results and do not reveal distinct impact of $\mathrm{ABO}$ mismatch upon the treatment outcomes $[8,12,13]$. Data ambivalence of ABO- and Rhesus-incompatibility impact in allo-HSCT, determined a rationale of a large cohort study, which would allow of creating more homogeneous comparison groups by the main parameters, and, therefore, increase the significance of results. The aim of our study was to specify the role of ABO-incompatibility in allo-HSCT for a well-characterized cohort of patients.

\section{Patients and methods}

From 1999 to 2015, 1132 patients with malignancies and hereditary diseases undergone 1482 allo-HSCT at the R. Gorbacheva Memorial Institute for Children Oncology,
Hematology and Transplantation (Tab. 2). 149 patients have received second graft, 13 of them - triple (in most cases, from the same donor).

Patients with acute myeloid leukemia $(n=568)$, acute lymphoblastic leukemia $(n=475)$, chronic myeloid leukemia $(n=94)$, myelodysplastic syndrome $(n=76)$, severe aplastic anemia $(n=57)$ represented the dominant clinical group. Over recent years, an increased allo-HSCT activity has been registered for orphan diseases $(n=49)$ and solid tumors in children $(n=9)$.

The choice of conditioning regimen was determined by diagnosis, disease status and patient somatic state. Myeloablative conditioning regimen (MAC) was used in 431 patients (29.5\%), non-myeloablative regimens (RIC), were applied in 1030 cases $(70.5 \%)$. Busulfan + cyclophosphamide drug combination $(n=301)$ was the most frequently used protocol (69.8\% of total MAC-treated group). RIC regimens, i.e., busulfan+ fludarabine, or melphalan+ fludarabine were used, respectively, in $515(50 \%)$ and $21 \%(n=217)$.

GvHD prophylaxis was carried out in accordance with European Group for Bone Marrow Transplantation (EBMT) Recommendations, R. Gorbacheva Memorial Institute for Children Oncology, Hematology and Transplantation policies, and include cyclophosphamide alone or combinations of immunosuppressive drugs: cyclosporine A, tacrolimus, sirolimus, with their pharmacokinetic control in serum; also combined with methotrexate, mycophenolate mofetil, antithymocyte globulin (ATG).

Evaluation engraftment and staging of posttransplant complications were made according to standard definitions and classifications [14-17], and EBMT 2012 Recommendations. The first detection of donor RBC in two or more consecutive peripheral blood tests by serological methods was considered to be the beginning of donor chimerism [18].

Standard laboratory techniques for ABO, Rh (D, C, c, E, e, K, $\mathrm{C}^{\mathrm{w}}$ ) and Cellano (Kell) evaluation were used: cross-method with monoclonal antibodies and micro-typing system (IDcard, Bio Rad). Direct antiglobulin test was made by standard gel method (ID Liss Coombs, DC-Screening I, Bio Rad Laboratories).

In order to reduce the risk of immune transfusion reactions in case of $\mathrm{ABO}$-incompatibility, graft manipulation technologies were used: in case of major ABO-incompatibility, removal of incompatible donor erythrocytes (sedimentation with $6 \%$ hydroxyethyl starch); in case of minor incompatibility, donor plasma was removed by centrifugation procedure; in case of bidirectional mismatch, a combination of the methods was used.

\section{Table 1. Different types of donor/recipient ABO incompatibility in allogeneic HSCT [6]}

\begin{tabular}{|l|l|l|l|l|}
\hline \multirow{2}{*}{$\begin{array}{l}\text { Patient, } \\
\text { RBC group }\end{array}$} & \multicolumn{4}{|c|}{ Donor } \\
\cline { 2 - 5 } & $0(\mathrm{II})$ & $\mathrm{A}(\mathrm{II})$ & $\mathrm{B}(\mathrm{III})$ & $\mathrm{AB}(\mathrm{IV})$ \\
\hline $\mathrm{O}(\mathrm{II})$ & - & Major & Major & Major \\
\hline $\mathrm{A}(\mathrm{II})$ & Minor & - & Bidirectional & Major \\
\hline $\mathrm{B}(\mathrm{III})$ & Minor & Bidirectional & - & Major \\
\hline $\mathrm{AB}(\mathrm{IV})$ & Minor & Minor & Minor & - \\
\hline
\end{tabular}


Table 2. Allo-HSCT recipient's characteristics

\begin{tabular}{|c|c|}
\hline Parameter & Data \\
\hline Allo-HSCT & $\mathrm{n}=1482$ \\
\hline $\begin{array}{l}\text { Age, median, range: } \\
\text { 1-21 years } \\
\text { >22 years }\end{array}$ & $\begin{array}{l}25(0-76) \\
n=712(48.6 \%) \\
n=752(51.4 \%)\end{array}$ \\
\hline $\begin{array}{l}\text { Recipient gender: } \\
\text { male } \\
\text { female }\end{array}$ & $\begin{array}{l}n=842(56.8 \%) \\
n=640(43.2 \%)\end{array}$ \\
\hline $\begin{array}{l}\text { Donor gender: } \\
\text { male } \\
\text { female }\end{array}$ & $\begin{array}{l}n=856(60.3 \%) \\
n=564(39.7 \%)\end{array}$ \\
\hline $\begin{array}{l}\text { Diseases: } \\
\text { Malignant disease } \\
\text { remission } \\
\text { progression/relapse } \\
\text { not applicable } \\
\text { Non-malignant disease }\end{array}$ & $\begin{array}{l}1371 \\
n=748(54.6 \%) \\
n=605(44.2 \%) \\
n=18(1.2 \%) \\
n=111\end{array}$ \\
\hline $\begin{array}{l}\text { HLA-type: } \\
\text { 10/10 full match } \\
\text { 9/10 mismatch }\end{array}$ & $\begin{array}{l}n=1002(69 \%) \\
n=449(31 \%)\end{array}$ \\
\hline $\begin{array}{l}\text { AB0-status: } \\
\text { compatible } \\
\text { incompatible }\end{array}$ & $\begin{array}{l}n=648(45.4 \%) \\
n=780(54.6 \%)\end{array}$ \\
\hline $\begin{array}{l}\text { Stem cell source: } \\
\text { bone marrow } \\
\text { peripheral blood stem cell } \\
\text { peripheral blood stem cell + bone marrow } \\
\text { cord blood }\end{array}$ & $\begin{array}{l}n=680(45.9 \%) \\
n=719(48.5 \%) \\
n=79(5.3 \%) \\
n=4(0.3 \%)\end{array}$ \\
\hline
\end{tabular}

If necessary, blood transfusion therapy was carried out according to $\mathrm{ABO}$-status and general recommendations [6].

Statistical analysis was performed using IBM SPSS Statistics version 13.0 by the rules and international recommendations for processing and providing the results of HSCT [19] and include following statistical methods: descriptive statistics for quantitative variables, parametric statistics, description of nominal variables (ABO-incompatibility impact assessment on the development of GvHD); overall survival (OS) analysis was performed by Kaplan-Mayer method using logrank test. To reveal the factors associated with engraftment terms, a logarithmic utility function (logworth) was used. The role of various factors influencing posttransplant period and chimerism development was assessed by multivariate analysis (Cox regression). The difference between individual indicators was considered statistically significant at $\mathrm{p}<0.05$.

\section{Results}

\section{Impact of $\mathrm{ABO}$ blood groups and Rhesus factor on the allo-HSCT effectiveness}

In the present study, comprehensive analysis on the impact of ABO- and Rhesus-incompatibility on allo-HSCT efficiency and risk of complications was performed. Patient's ABO blood group, as an independent parameter, did not affect 1 -year OS in patients with malignant diseases in allo-HSCT $(\mathrm{n}=1366), \mathrm{p}=0.48$. At the same time, negative $(\mathrm{n}=186)$ or positive $(n=1180)$ Rhesus factor in the patients proved to be a valuable predictive marker, since its negative status affected 1 -year OS in allo-HSCT - 48\%, with respective average value of 8.1 months, (HR 0.324; 95\% CI $7.553-8.822$ ), and 59\% (average - 8.8 months, HR 0.126; 95\% CI 8.605 - 9.101), being significantly different at $\mathrm{p}=0.01$ (Fig. 1).

Rhesus system antigens have a much lower degree of immunogenicity compared to potential effects of $\mathrm{ABO}$ system, but it can contribute to allo-sensibilisation and promotion of hemolytic complications, thereby reducing the efficiency of allo-HSCT, which was confirmed in this study. When comparing pre-transplant $\mathrm{RBC}$ phenotypes in the patients with malignancies $(n=1175)$, the following combinations have been found to affect the one-year OS (Fig. 2):

- DCCee $(\mathrm{n}=197)$ vs ddccee $(\mathrm{n}=157), 65 \%$ (mean, 9.5 months; HR 0.283; 95\% CI 8.945-10.056) and 50\% (median, 11.4 months; HR 0.348; 95\% CI 7.706-9.069), respectively, $\mathrm{p}=0.006$;

- Dccee $(\mathrm{n}=450)$ vs ddccee ( $\mathrm{n}=157), 63 \%$ (mean - 9 months, HR 0.198; 95\% CI 8.672-9.45) and 50\%, respectively, $\mathrm{p}=0.025$.

Studying clinical effects and outcomes depending on the Rh antigen status of the donor $(n=998)$ confirm the assumption of a more pronounced negative effects of homozygous and 
D-negative $\mathrm{Rh}$ phenotypes upon overall patient survival (Fig. 3):

- DCcEe $(\mathrm{n}=124)$ vs DCcee $(\mathrm{n}=389), 67 \%$ and $58 \%$, respectively, $(\chi 2-5.454) \mathrm{p}=0.019$;

- DCcEe $(\mathrm{n}=124) v s$ ddccee $(\mathrm{n}=158), 67 \%$ and $53 \%$, respectively, $(\chi 2-5.985) \mathrm{p}=0.014$.

Thus, presence of negative Rhesus factor in the patients $(\mathrm{p}=0.01)$ corresponding to the ddccee phenotype $(\mathrm{p}=0.006)$, and negative Rhesus factor in graft donor (ddccee phenotype, $\mathrm{p}=0.014$ ), is associated with a decrease in 1-year OS in patients with malignant diseases, compared with patient's positive Rhesus and phenotypes DCCee, Dccee and graft donor's phenotype DCcEe, respectively.

\section{The impact of $\mathrm{ABO}-$-mismatches on $\mathrm{OS}$ and the risk of GvHD development in allo-HSCT}

In our study, ABO-incompatibility $(\mathrm{n}=1428)$ was documented in $54.6 \%$ of allo-HSCT cases $(n=780)$, with major or minor mismatch shown, respectively in $37.8 \%(n=295)$, and $45.4 \%$ of the cases $(n=354)$; and bidirectional incompatibility having been registered in $16.8 \%$ of the cohort $(n=131)$, which is slightly more frequent compared to the worldwide data [4], due to specific variability of the gene polymorphisms in the multinational population of Russian Federation, and a significant number of grafts from the foreign unrelated donors used at our HSCT Center.

The authors opinion and literature data on the impact of ABO-incompatibility on OS are contradictory since most of them did not prove a negative influence upon HSCT outcome. However, the 10-year experience of French BMT group $(n=1108)$ indicate to a negative impact of minor ABO-incompatibility in allo-HSCT patients treated with RIC combination with fludarabine and low-dose total body irradiation or fludarabine and busulfan with rabbit ATG, along with absence of remission, and inclusion of ATG $>10 \mathrm{mg} / \mathrm{kg}$ into the GvHD prophylaxys schemes [20].

According to our data, minor ABO-incompatibility in patients with leukemia in remission $(n=600)$ was associated with reduced $\mathrm{D}+100$ OS rates when compared with ABO-compatible allo-HSCT, $\mathrm{p}=0.05$ (Fig. 4): in ABO-compatible patient/donor HSCT, $91 \%(n=262$, a mean of 95 days, HR 0.998; 95\% CI 93.32-97.23); for major ABO-incompatibility, 85\% ( $\mathrm{n}=117$, a mean of 92 days, HR 1.809; 95\% CI 89.088-96.179); for minor ABO mismatches, $85 \%(n=163$, an average value of 92 days, HR 1.527; 95\% CI 89.324-95.309), and for bidirectional incoompatibility, 93\% $(n=58$, average level of 95 days, HR 1.703; 95\% CI 93.207-99.883), respectively.

Further analysis was performed according to the type of $\mathrm{ABO}$-incompatibility in combination with conditioning regimens, GvHD prophylaxis, taking into account different degree of myeloablation, mechanisms of immunosuppression and possible risk potentiation for immune complications.

A combination of MAC and major ABO-incompatibility in patients with leukemia in remission $(n=215)$ was found to be associated with a decreased OS at 100-days after alloHSCT, if compared with ABO-compatible allo-HSCT,

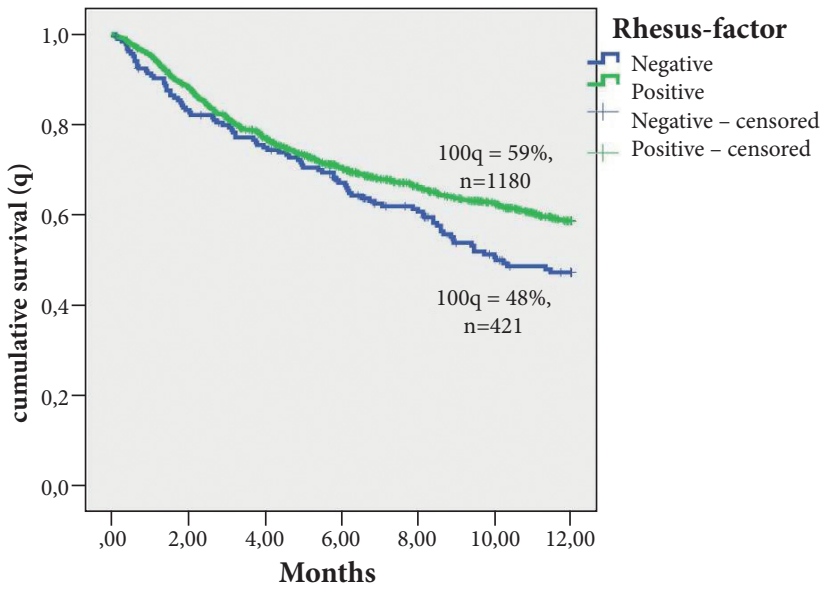

Figure 1. One-year OS in patients with malignant diseases after allo-HSCT depending on the patient's $R \boldsymbol{h}$ status

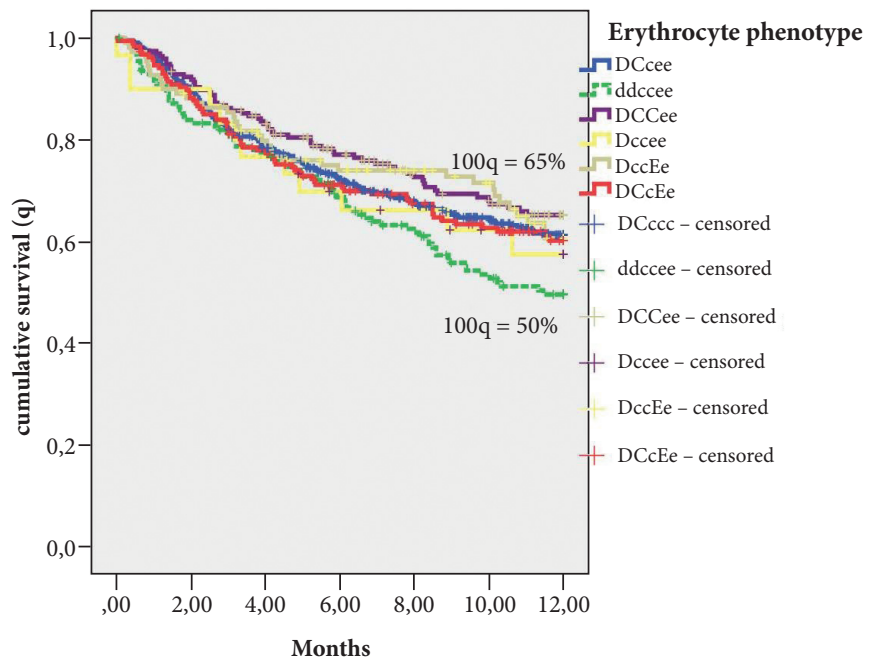

Figure 2. One-year $0 S$ in patients with malignant diseases after allo-HSCT, depending on the patient's erythrocytes $R h$ phenotype

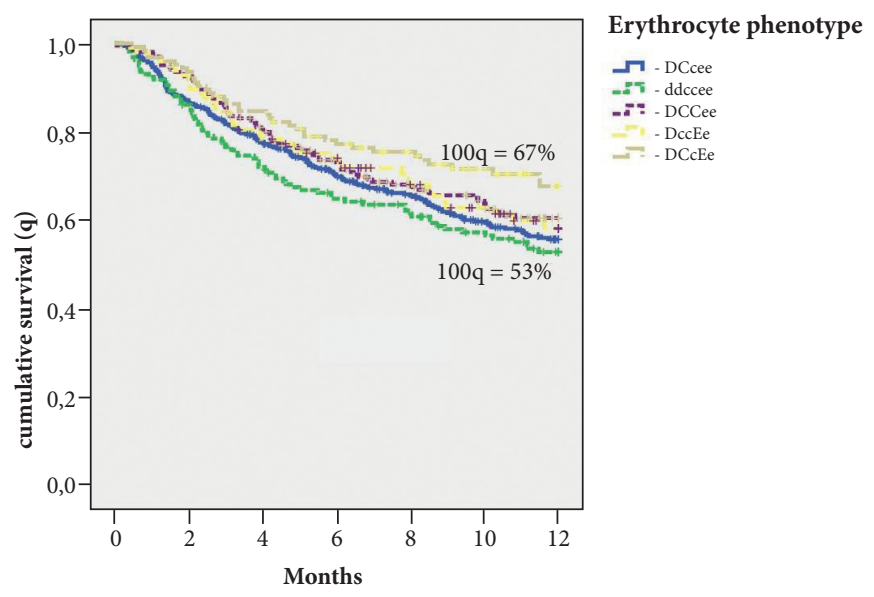

Figure 3. One-year OS in patients after allo-HSCT, depending on graft donor's erythrocyte phenotype 
$\mathrm{p}=0.025$ (Fig. 5) which should be taken into account when choosing the conditioning treatment mode. I.e., the OS value for ABO-compatible patients $(n=103)$ was $91 \%$ (average of 95 days, HR 1.598; 95\% CI 91.885-98.148), in the pairs with major ABO-incompatibility $(\mathrm{n}=37)$, the OS value was $76 \%$ (average, 88 days, HR 3.765; 95\% CI 80.95-95.709). The 100 -d OS in cases of minor ABO mismatch $(n=56)$ was $82 \%$ (average, 91 days, HR 2.762; 95\% CI 86.039-96.868); for bidirectional incompatibility, $(\mathrm{n}=19)$, the OS was $89 \%$ (average, 93 days, HR 4.364; 95\% CI 84.831-101.937).

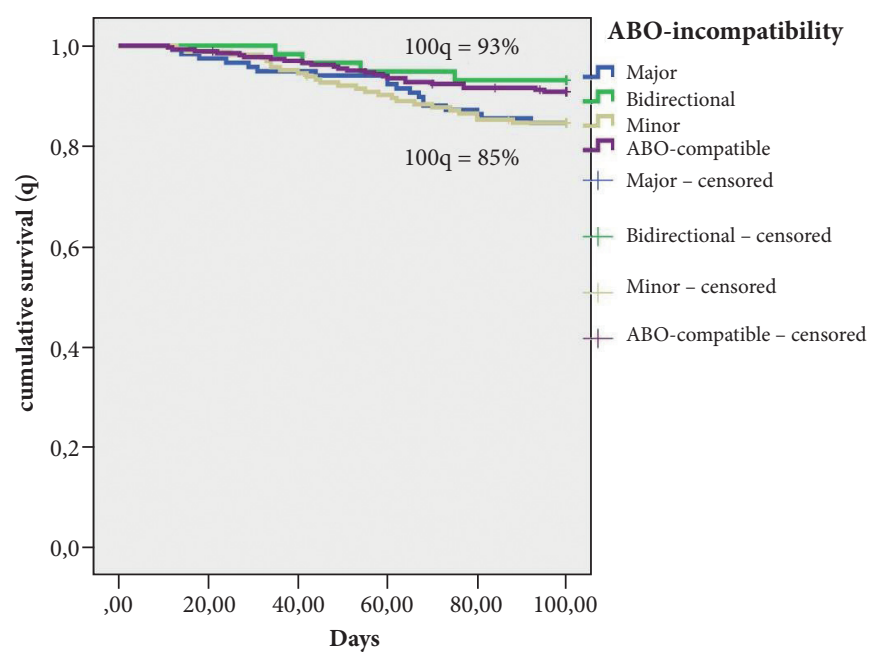

Figure 4. 05 rates for the $D+100$, depending on the type of $\mathrm{ABO}$-incompatibility in patients with leukemia in remission with allo-HSCT

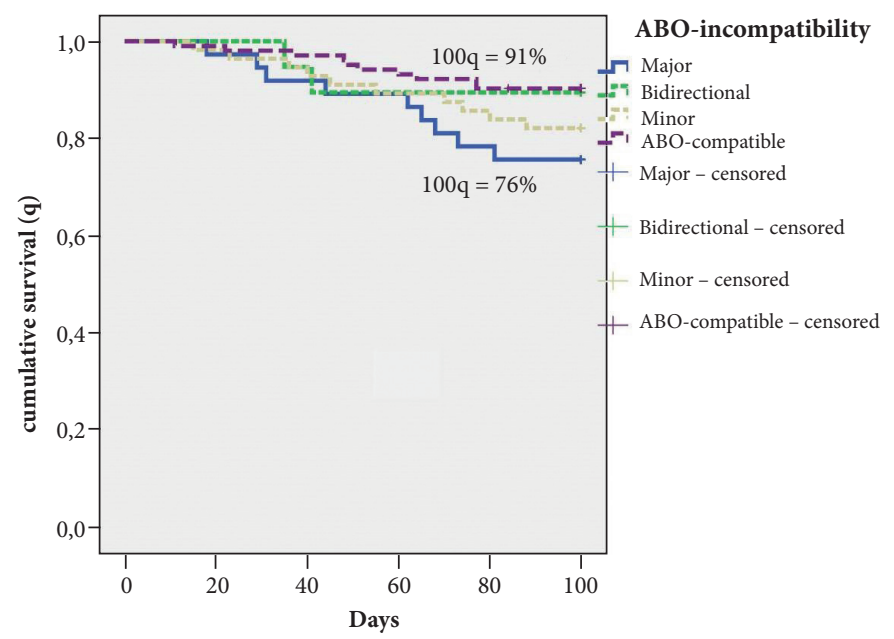

Figure 5. 05 rates on $D+100$ depending on the type of ABO-incompatibility and MAC in patients with leukemia in remission

\section{Discussion}

A high risk for ABO-incompatibility is an additional factor potentiating immunological reactivity, thus increasing risk of GvHD and possible hemolytic complications remains controversial. A number of publications noted higher frequency of acute GvHD grade III-IV in the case of major and minor $\mathrm{ABO}$-incompatibility [21]. On the other hand, a group of scientists from Seattle presented data from the large US National Bone Marrow Donor Program showing no significant difference in the development of acute GvHD depending on the ABO-incompatibility type [22].

Results of our study indicate that the type of ABO-incompatibility: major $(n=123)$, minor $(n=167)$ or bidirectional $(n=61)$ did not increase either severity, or incidence of acute GvHD (grade I-IV) in patients with leukemia transplanted in remission $(n=626)$, compared to ABO-compatible HSCT $(\mathrm{n}=275), \mathrm{p}=0.85$. Acute GvHD developed in ABO-compatible HSCT in $52 \%$ of cases $(n=143)$, in major ABO-incompatibility, 48.8\% $(\mathrm{n}=60)$, in minor ABO-mismatch, 50.9\% $(\mathrm{n}=85)$, in bidirectional mismatch, 55.7\% $(\mathrm{n}=34)$, respectively.

Likewise, the type of ABO-incompatibility: major $(n=123)$, minor $(n=167)$, bidirectional $(n=61)$; did not increase the risk of chronic GvHD in patients with leukemia treated in remission $(n=626)$ compared to ABO-compatible HSCT $(\mathrm{n}=275), \mathrm{p}=0.21$. Chronic GvHD developed in ABO-compatible HSCT in $26.5 \%$ of cases $(n=73)$; in major ABO-incompatibility, $24.4 \%$ of cases $(n=30)$; in minor, $24 \%$ of cases $(\mathrm{n}=40)$; in bidirectional, $37.7 \%(\mathrm{n}=23)$, respectively.

\section{The impact of ABO-incompatibility on engraft- ment}

According to the results of our study, in general cohort of patients with allo-HSCT, the leukocyte recovery $>1.0 \times 109 / 1$ was observed on day 18 (mean \pm standard deviation $-20 \pm 10.4$ ); neutrophil recovery $>0.5 \times 10^{9} / 1$ - on day $17(20.5 \pm 13.6)$; platelet recovery $>20 \times 10^{9} / 1-$ on day $14(21 \pm 17.8)$; platelet recovery $>50 \times 10^{9} / 1-$ on day $16(23.2 \pm 15)$. The most significant factors which determined time of engraftment were as follows: HLA-match (logworth, 15.1), graft source (logworth, 7.05), type of allo-HSCT (logworth 6.4), conditioning regimen (logworth, 4.05). The factors which increased the engraftment time were as follows: 9/10 HLA-match, MAC regimen, bone marrow as a source of transplant. In turn, ABO- and Rhesus-incompatibility had a much smaller impact on neutrophils and platelets engraftment timeline: ABO-incompatibility (logworth of 0.87 ), blood group of the donor (logworth, 0.34 ), patient's erythrocyte phenotype (logworth, 0.33), donor's Rhesus factor (logworth, 0.27), donor's erythrocyte phenotype (logworth, 0.001).

However, as exemplified by 240 recipients of allo-HSCT, the differences in recovery time of erythrocyte counts on D+50 proved to be dependent on $\mathrm{ABO}$-incompatibility, i.e., the patients from ABO-compatible donor/patient pairs achieved $\mathrm{RBC}$ recovery in $23.8 \%$ of cases, and those with $\mathrm{ABO}$-incompatibility, in $10 \%(\mathrm{p}=0.01)$.

The results of this study suggest that the $100 \%$ donor chimerism for ABO blood groups was reached in 159 of 240 patients (17 to 229 days, a median of 84 days). In 81 patients, the results could not be assessed due to their death in early posttransplant period $(n=50)$; inability to identify differences, due to identity for ABO-, Rhesus-system (D, C, c, E, e) and Kell markers $(n=7)$; lack of laboratory data due to incomplete patient's data obtained posttransplant $(n=24)$. 
Primary diagnosis $(p=0.87)$, disease status $(p=0.69)$, allo-HSCT type $(p=0.26)$, graft source $(p=0.28)$, degree of HLA match $(\mathrm{p}=0.62)$ and conditioning regimens $(\mathrm{p}=0.39)$ did not have a negative impact on blood group conversion terms. ABO-incompatibility was the only identified factor increasing chimerism time development $(\mathrm{p}=0.0001)$. For ABO-compatible allo-HSCT with Rh incompatibility $(n=52)$, the time to achieve $100 \%$ chimerism was $95 \pm 44$ days (31-226 days, HR 6,106; 95\% CI 82.9-107.4), with major ABO-incompatibility $(\mathrm{n}=29)-109 \pm 51$ days (27-229 days, HR 9.642; 95\% CI 89.9-129.4), with minor $(n=57)-67 \pm 22$ days (17-109 days, HR 3,032; 95\% CI 61-73,1), with bidirectional mismatches $(\mathrm{n}=21)-72 \pm 16$ days (48-117 days, HR 3,515; 95\% CI 65,3-80).

Negative effect of ABO-incompatibility type on erythroid time recovery, is reflected in posttransplant transfusion therapy intensiveness $(p=0,003)$. The average number of transfusions of blood components was 25 units in major ABO-incompatibility $(\mathrm{p}=0.001) ; 16.5$, in minor mismatch $(\mathrm{p}=0.006)$; 13.6, in bidirectional ( $\mathrm{p}=0.005) ; 15.1$, in ABO-compatible allo-HSCT $(\mathrm{p}=0.001)$, respectively.

\section{HSCT complications associated with ABO-incom- patibility}

Additional attention is paid to the development of specific complications associated with ABO-incompatibility. Clinical manifestations in this case may be due to localization of $\mathrm{ABO}$ system antigens, which are represented not only on erythrocytes, but also on other cells and tissues: platelets, lymphocytes, endothelium of blood vessels and organs (kidneys, liver, heart) circulating in plasma [23].

According to our data, the risk of immune complications in allo-HCT $(\mathrm{n}=1158)$ is $2.8 \%(\mathrm{n}=33)$ versus $4.1 \%$ in the presence of ABO-incompatibility $(n=638, p=0.02)$, as seen from Table 3. A low number of cases and mortality $(n=3)$ may indicate adequate prevention, timely and effective treatment.

\section{Design of OS predictive models in allo-HSCT}

One of the main objectives in multivariate analysis was to identify factors and their combinations that affect OS in allo-HSCT, and to create a mathematical model for predicting the probability of potential complications, which will allow for timely prophylaxis and treatment. The study was based on Cox regression with preliminary exploratory analysis for patients with malignant diseases, which was performed as a Kaplan-Meier test for nominal variables-factors affecting the outcome of treatment [24]. As a result of the analysis, the following predictors affecting OS were identi- fied: degree of HLA-match, presence of acute GvHD, major ABO-incompatibility, allo-HSCT type, status of the underlying disease, and use of ATG for GvHD prophylaxis (Fig. 6).

Our valid predictive model of 100-day OS may serve such an example, which included patients with leukaemia $(n=140)$ from 9/10 HLA-matched related and unrelated donor, in case of engraftment up to D+31 (Fig. 7).

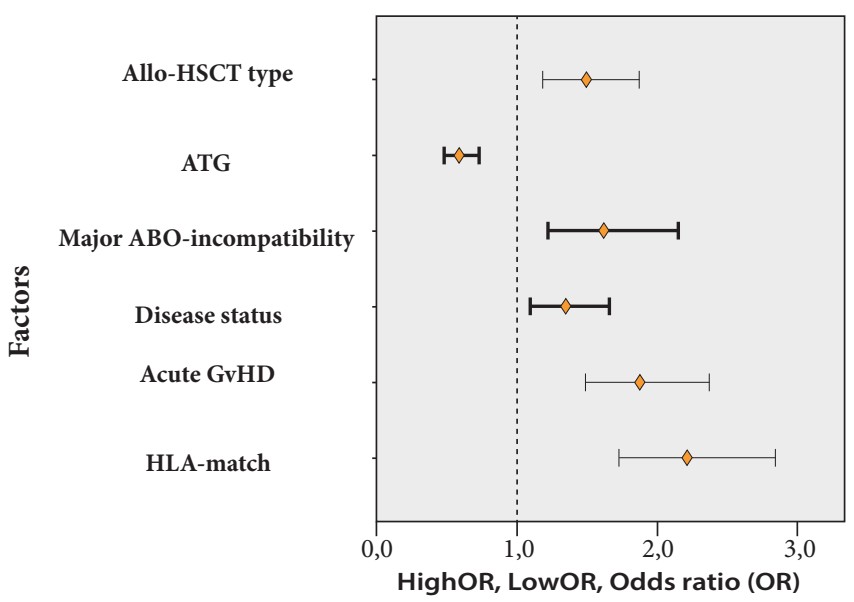

Figure 6. OS predictors in allo-HSCT patients with malignant diseases

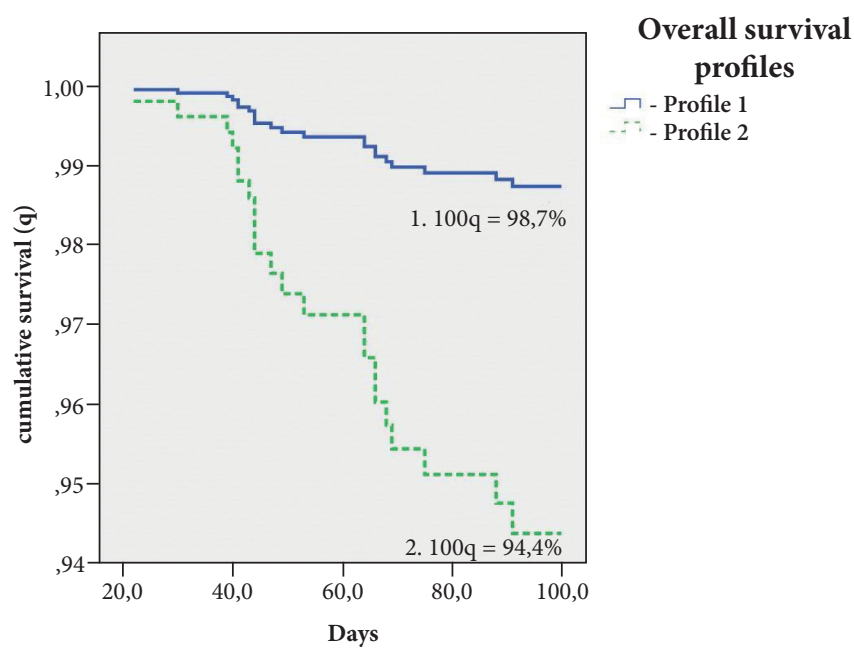

Figure 7. 100-day OS predictive model in patients with allo-HSCT with 9/10 HLA-match with engraftment up to $\mathrm{D}+31$

Note: Profile 1: MAC, major ABO-incompatibility, GvHD prophylaxis - cyclophosphamide containing schemes; Profile 2: MAC, major ABO-incompatibility, GvHD prophylaxis «cyclosporine A + methotrexate» or «tacrolimus + methotrexate».

Table 3. Development of immune complications in allo-HSCT depending on the ABO-incompatibility type

\begin{tabular}{|l|l|l|l|l|l|l|}
\hline \multirow{2}{*}{ Complication } & \multicolumn{5}{|l|}{} & \multirow{2}{*}{$\mathrm{p}$} \\
\cline { 2 - 5 } & \multirow{2}{*}{ All } & \multicolumn{2}{|l|}{ ABO-incompatibility } & \\
\cline { 3 - 6 } & & Compatible & Major & Minor & Bidirectional & \\
& 1158 & 510 & 237 & 294 & 117 & \\
\hline Immune hemolysis & 19 & 4 & 7 & 6 & 2 & 0,02 \\
PRCA & 9 & 0 & 9 & 0 & 0 & \\
Immune thrombocytopenia & 5 & 2 & 2 & 1 & 0 & \\
\hline
\end{tabular}




\section{Conclusion}

The data presented in this study suggest that $\mathrm{ABO}$-incompatibility may be a negative factor reducing effectiveness of treatment in allo-HSCT, especially in the early posttransplantation period and during the first year posttransplant. Adverse effects of ABO-incompatibility are realized through allosensitization, increasing the frequency of hemolytic complications and delaying erythroid recovery.

It seems that the main tool for minimizing the ABO-incompatibility consequences is the donor graft preparation based on ABO-incompatibility type, which allows achieving low frequency and severity of possible hemolytic complications.

The next factor of important value is the replacement transfusion therapy, which should be based on red blood cells chimerism level and comply with the principles to use the most leukocyte depleted blood components, which can improve the efficiency of blood transfusions and reduce the risk of posttransfusion reactions and complications.

Thus, when choosing an allogeneic bone marrow donor, giving priority to a higher degree of HLA-match and CMV-status in "recipient-donor" pair, it is also optimal to choose, if possible, an ABO- and Rhesus compatible donor.

\section{Conflict of interests}

The authors have no conflict of interest to declare.

\section{References}

1. Zander AR. Stem cell transplantation for myeloproliferative diseases in the era of molecular therapy. Cell Ther Transplant. 2017; 6(4): 21-27.

2. Afanasyev BV, Zubarovskaya LS, Moiseev IS. Allogeneic hematopoietic stem cell transplantation in children: state of art, issues and prospects. Russian Journal of Pediatric Hematology and Oncology. 2015; 2(2); 28-42 (In Russian).

3. Rowley SD, Donato ML, Bhattacharyya P. Red blood cell-incompatible allogeneic hematopoietic progenitor cell transplantation. Bone Marrow Transplantation. 2011; 46; 1167-1185.

4. Worel N. ABO-mismatched allogeneic hematopoietic stem cell transplantation. Transfus Med Hemother. 2016; 34:3-12.

5. Sidorkevich SV, Akimova OV, Petrenko GI, Belyakov MV, Martynova MV, Kolesov AA, Chernikova ES, Savicheva IV. Transfusion support in hematopoietic stem cell transplantation in patients with malignancy. Transfusiology. 2014;15(2): 93-94 (In Russian).

6. Booth GS, Gehrie EA, Bolan CD, Savani BN. Clinical guide to $\mathrm{ABO}$-incompatible allogeneic stem cell transplantation. Biol Blood Marrow Transplant. 2013; 13: 1152-1158.

7. Worel N, Greinix HT, Schneider B, Kurz M, Rabitsch W, Knöbl P, Reiter E, Derfler K, Fischer G, Hinterberger W, Höcker P, Kalhs P. Regeneration of erythropoiesis after related- and unrelated-donor BMT or peripheral blood HPC transplantation: a major $\mathrm{ABO}$ mismatch means problems. Transfusion. 2000;40: 543-550.

8. Seebach JD, Stussi G, Passweg JR, Loberiza FR Jr, Gajewski JL, Keating A, Goerner M, Rowlings PA, Tiberghien P, Elfenbein GJ, Gale RP, van Rood JJ, Reddy V, Gluckman E, Bolwell BJ, Klumpp TR, Horowitz MM, Ringdén O, Barrett AJ. ABO blood group barrier in allogeneic bone marrow transplantation revisited. Biol Blood Marrow Transplant. 2005;11:1006-1013.

9. Remberger M, Watz E, Ringden O, Mattsson J, Shanwell A, Wikman A. Major ABO blood group mismatch increases the risk for graft failure after unrelated donor hematopoietic stem cell transplantation. Biol Blood Marrow Transplant. 2007; 13:675-682.

10. Ahmed I, Teruya J, Murray-Krezan C, Krance R. The incidence of autoimmune hemolytic anemia in pediatric hematopoietic stem cell recipients post first and second hematopoietic stem cell transplant. Pediatr Transplant. 2015;19(4):391-398.

11. Jagasia M, Arora M, Flowers MED, Chao NJ, McCarthy PL, Cutler CS, Urbano-Ispizua A, Pavletic SZ, Haagenson MD, Zhang MJ, Antin JH, Bolwell BJ, Bredeson C, Cahn JY, Cairo M, Gale RP, Gupta V, Lee SJ, Litzow M, Weisdorf DJ, Horowitz MM, Hahn T. Risk factors for acute GVHD and survival after hematopoietic cell transplantation. Blood 2012;119:296-307.

12. Atay D, Erbey F, Akcay A, Ozturk G. Is ABO mismatch another risk factor for allogeneic hematopoietic stem cell transplantation in pediatric thalassemic patients? Pediatr Transplant 2015; 19(6); 645-651.

13. Gutiérrez-Aguirre CH, Gómez-De-León A, Alatorre-Ricardo J, Cantú-Rodríguez OG, González-Llano O, Jaime-Pérez JC, Mancías-Guerra C, Flores-Jiménez JA, Gómez-Almaguer D. Allogeneic peripheral blood stem cell transplantation using reduced-intensity conditioning in an outpatient setting in $\mathrm{ABO}$-incompatible patients: are survival and graft-versus-host disease different? Transfusion. 2014;54(5):1269-1277.

14. Przepiorka D, Weisdorf D, Martin P. 1994 Consensus Conference on acute GVHD grading. Bone Marrow Transplant. 1995;15:825.

15. Filipovich AH, Weisdorf D, Pavletic S, Socie G, Wingard JR, Lee SJ, Martin P, Chien J, Przepiorka D, Couriel D, Cowen EW, Dinndorf P, Farrell A, Hartzman R, Henslee-Downey J, Jacobsohn D, McDonald G, Mittleman B, Rizzo JD, Robinson M, Schubert M, Schultz K, Shulman H, Turner M, Vogelsang G, Flowers ME. National Institutes of Health Consensus development project on criteria for clinical trials in chronic graft-versus-host disease: I. Diagnosis and Staging Working Group Report. Biol Blood Marrow Transplant. 2005;11:945-955.

16. Jagasia MH, Greinix HT, Arora M, Williams KM, Wolff D, Cowen EW, Palmer J, Weisdorf D, Treister NS, Cheng GS, Kerr H, Stratton P, Duarte RF, McDonald GB, Inamoto Y, Vigorito A, Arai S, Datiles MB, Jacobsohn D, Heller T, Kitko 
CL, Mitchell SA, Martin PJ, Shulman H, Wu RS, Cutler CS, Vogelsang GB, Lee SJ, Pavletic SZ, Flowers ME. National Institutes of Health Consensus development project on criteria for clinical trials in chronic graft-versus-host disease: I. The 2014 Diagnosis and Staging Working Group Report. Biol Blood Marrow Transplant. 2015; 21(3): 389-401.

17. The National Hematology Society. Clinical guidelines for the diagnosis and treatment of acute myeloid leukemia in adults. II Congress of Hematologists of Russia 2014 (In Russian).

18. Ortho BioVue System Handbook 2015: 1-37.

19. Szydlo RM. Statistical Evaluation of SCT data, haematopoietic stem cell transplantation. The EBMT Handbook, 6th Edition (Eds: Apperley, Carreras, Gluckman, Masszi) // Publ: European School of Haematology 2012: 612-628.

20. Michallet M, Le QH, Mohty M, Prébet T, Nicolini F, Boiron JM, Esperou H, Attal M, Milpied N, Lioure B, Bordigoni P, Yakoub-Agha I,Bourhis JH, Rio B,Deconinck E, Renaud M, Chir Z, Blaise D. Predictive factors for outcomes after reduced intensity conditioning hematopoietic stem cell transplantation for hematological malignancies: a 10-year retrospective analysis from the Société Française de Greffe de Moelle et de Thérapie Cellulaire. Exp Hematol 2008; 36:535-544.

21. Kimura F, Sato K, Kobayashi S, Ikeda T, Sao H, Okamoto S, Miyamura K, Mori S, Akiyama H, Hirokawa M, Ohto $\mathrm{H}$, Ashida H, Motoyoshi K. Impact of ABO-blood group incompatibility on the outcome of recipients of bone marrow transplants from unrelated donors in the Japan Marrow Donor Program. Haematologica 2008; 93:1686-1693.

22. Goldman J, Liesveld J, Nichols D, Heal J, Blumberg N. $\mathrm{ABO}$ incompatibility between donor and recipient and clinical outcomes in allogeneic stem cell transplantation. Leuk Res. 2003;27: 489-491.

23. Gehrie EA, Cates JM, Nian H, Olson SJ, Young PP. Blood group A antigen expression on cardiac endothelium is highly individualized: Possible implications for transplantation. Cardiovasc Pathol 2013; 22:251-256.

24. Kleinbaum DG, Klein M. Survival Analysis. A Self-Learning Text. Second Edition, Springer Science \& Business Media, Inc 2005. 


\title{
Роль АВ0- и резус-несовместимости при аллогенной трансплантации гемопоэтических стволовых клеток
}

\author{
Максим А. Кучер ${ }^{1}$, Дмитрий Э. Певцов ${ }^{1}$, Полина С. Куга ${ }^{1}$, Борис И. Смирнов ${ }^{1,2}$, Александр Л. Алянский ${ }^{1}$, \\ Наталья Е. Иванова ${ }^{1}$, Мария А. Эстрина ${ }^{1}$, Елена В. Бабенко ${ }^{1}$, Бурхонидин Б. Баховадинов ${ }^{1}$, \\ Людмила С. Зубаровская ${ }^{1}$, Борис В. Афанасьев ${ }^{1}$ \\ ${ }^{1}$ НИИ детской онкологии, гематологии и трансплантологии им. Р. М. Горбачевой; ФГБОУ ВО «Первый Санкт-Петер- \\ бургский государственный медицинский университет им. акад. И. П. Павлова» Министерства здравоохранения России \\ ${ }^{2}$ Санкт-Петербургский государственный электротехнический университет «ЛЭТИ», Санкт-Петербург, Россия
}

\section{Резюме}

В настоящее время существуют противоречивые данные о негативном влиянии АВО-несовместимости на вероятность развития осложнений и эффективность лечения при аллогенной трансплантации гемопоэтических стволовых клеток (алло-ТГСК). Целью работы было изучение роли антигенов АВО-несовместимости при алло-ТГСК.

\section{Пациенты и методы}

В исследование включено 1132 пациента с гематологическими, онкологическими и наследственными заболеваниями, которым было выполнено 1482 алло-ТГСК. Возраст составил 6 месяцев - 76 лет, медиана - 25 лет. Проведен комплексный статистический анализ, направленный на определение влияния AВО-несовместимости как изолированного фактора, так и в комбинации с другими факторами при аллоТГСК в различных группах сравнения, созданы прогностические модели общей выживаемости (ОВ).

\section{Результаты}

АВО-несовместимость определялась в 54,6\% случаев $(\mathrm{n}=780)$ : большая - 37,8\% (n=295); малая $-45,4 \%$ $(\mathrm{n}=354)$; комбинированная - 16,8\% (n=131). У пациентов с лейкозами негативное влияние на ОВ Д+100 оказала малая АВО-несовместимость по сравнению с АВО-совместимыми алло-ТГСК - 85\% и 91\%, $\mathrm{p}=0,05$. Комбинация миелоаблативного режима кондиционирования и большой $\mathrm{ABO}$-несовместимости $(n=37)$ в раннем периоде (Д+100) снижала ОВ по сравнению с АВО-совместимыми ТГСК (n=103) $76 \%$ и $91 \%, \mathrm{p}=0,025$. Наличие АВО-несовместимости не увеличивало вероятность развития острой и хронической реакции «трансплантат против хозяина» у пациентов с лейкозами, $\mathrm{p}=0,85$.

\section{Заключение}

АВО-несовместимость может приводить к снижению эффективности лечения при алло-ТГСК в раннем периоде и в течение первого года при совпадении ряда взаимопотенцирующих факторов, что требует выбора АВО-совместимого донора гемопоэтических стволовых клеток при наличии такой возможности и предъявляет повышенные требования иммуногематологической безопасности при заместительных трансфузиях компонентов крови.

\section{Ключевые слова}

Трансплантация гемопоэтических стволовых клеток, АВО-несовместимость, осложнения. 